BMC

Microbiology

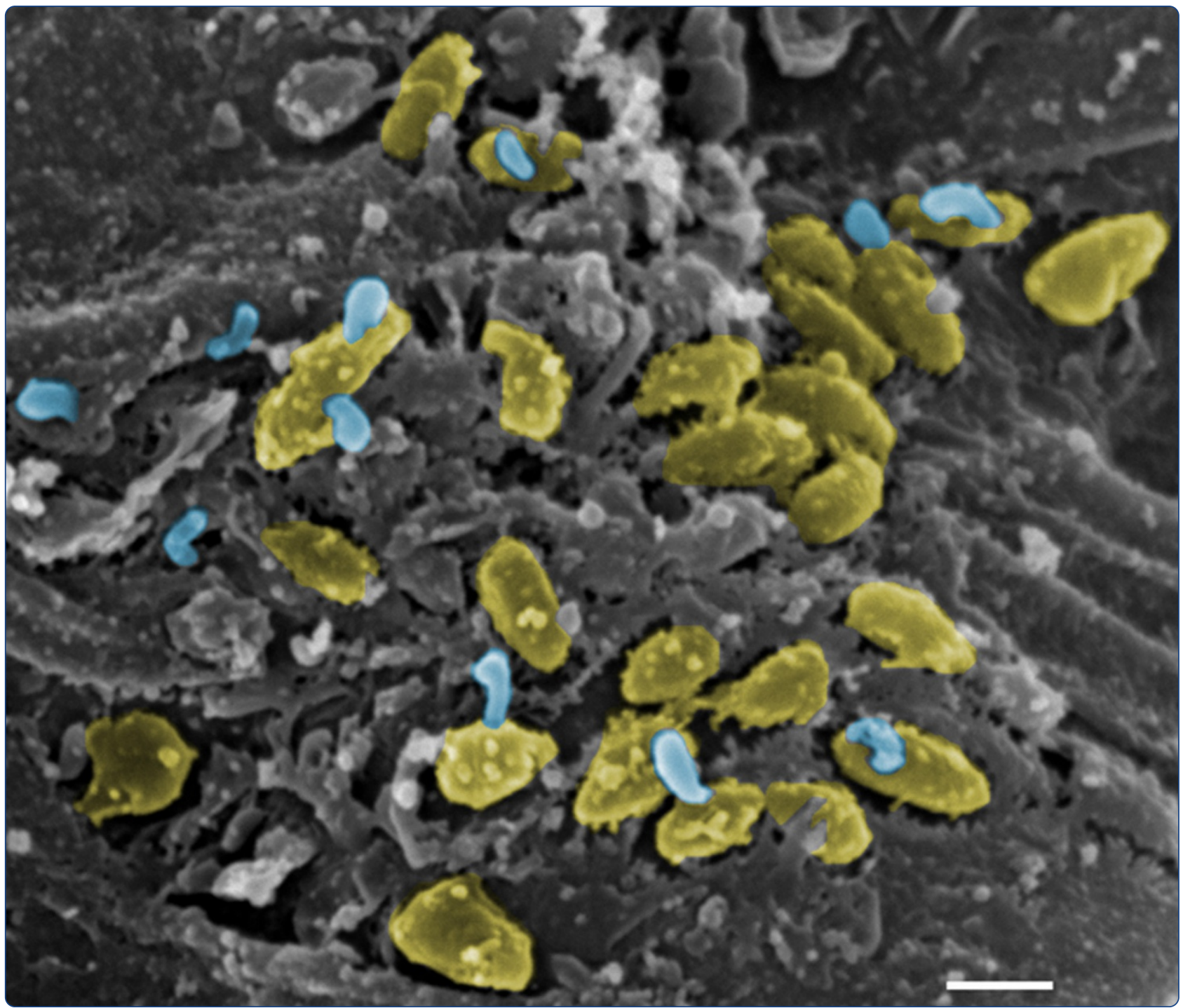

Bdellovibrio bacteriovorus HD100 guards against Pseudomonas tolaasii brown-blotch lesions on the surface of post-harvest Agaricus bisporus supermarket mushrooms

Saxon et al.

C Biomed Central 


\title{
Bdellovibrio bacteriovorus HD100 guards against Pseudomonas tolaasii brown-blotch lesions on the surface of post-harvest Agaricus bisporus supermarket mushrooms
}

\author{
Emma B Saxon ${ }^{1}$, Robert W Jackson², Shobita Bhumbra' ${ }^{1}$ Tim Smith $^{1}$ and R Elizabeth Sockett ${ }^{1 *}$
}

\begin{abstract}
Background: Pseudomonas tolaasii is a problematic pathogen of cultured mushrooms, forming dark brown 'blotches' on mushroom surfaces and causing spoilage during crop growth and post-harvest. Treating P. tolaasii infection is difficult, as other, commensal bacterial species such as Pseudomonas putida are necessary for mushroom growth, so treatments must be relatively specific.

Results: We have found that $P$. tolaasii is susceptible to predation in vitro by the $\delta$-proteobacterium Bdellovibrio bacteriovorus. This effect also occurred in funga, where B. bacteriovorus was administered to post-harvest mushroom caps before and after administration of the $P$. tolaasii pathogen. A significant, visible improvement in blotch appearance, after incubation, was observed on administration of Bdellovibrio. A significant reduction in viable P. tolaasii cell numbers, recovered from the mushroom tissue, was detected. This was accompanied by a more marked reduction in blotch severity on Bdellovibrio administration. We found that there was in some cases an accompanying overgrowth of presumed-commensal, non-Pseudomonas bacteria on post-harvest mushroom caps after Bdellovibrio-treatment. These bacteria were identified (by 16SrRNA gene sequencing) as Enterobacter species, which were seemingly resistant to predation. We visualised predatory interactions occuring between B. bacteriovorus and P. tolaasii on the post-harvest mushroom cap surface by Scanning Electron Microscopy, seeing predatory invasion of $P$. tolaasii by $B$. bacteriovorus in funga. This anti-P. tolaasii effect worked well in post-harvest supermarket mushrooms, thus Bdellovibrio was not affected by any pre-treatment of mushrooms for commercial/consumer purposes.
\end{abstract}

Conclusions: The soil-dwelling B. bacteriovorus HD100 preys upon and kills P. tolaasii, on mushroom surfaces, and could therefore be applied to prevent spoilage in post-harvest situations where mushrooms are stored and packaged for sale.

\section{Background}

Pseudomonas tolaasii is a Gram-negative, naturally soildwelling bacterial pathogen that causes brown blotch disease in several varieties of cultivated mushrooms [1-3]. The disease is characterised by brown lesions on the outer layers (2-3 $\mathrm{mm}$ depth) of the mushroom pileus and stipe, which range from small, light brown spots to larger, dark, sunken and wet lesions, depending on disease severity.

\footnotetext{
* Correspondence: liz.sockett@nottingham.ac.uk

'Genetics, School of Life Sciences, University of Nottingham, Medical School, Queen's Medical Centre, Nottingham NG7 2UH, UK

Full list of author information is available at the end of the article
}

This brown discolouration results from mushroom production of melanin, which is a defence response induced in this case by $P$. tolaasii producing the toxin tolaasin. Tolaasin is an 18-amino acid lipodepsipeptidide that forms ion channels and also acts as a biosurfactant to disrupt the plasma membrane of mushroom cells, allowing P. tolaasii access to cell-nutrients [4-7]. Infection is also reported to result in slower development of the mushroom crop with a lower yield [8]. The economic impact of the disease is significant, resulting in loss of visual appeal to consumers and regular crop reductions of $5-10 \%$ in the UK [9]. The disease is found worldwide: 
P. tolaasii mushroom infection has been documented in several countries, including the USA, Spain, Serbia, the Netherlands, Japan and Korea [1,2,10-13].

A major obstacle in the control of $P$. tolaasii infection that contributes to its broad prevalence is that some of the bacterial species present in the casing soil around mushrooms, such as Pseudomonas putida, are necessary for promoting the initial stages of mushroom growth $[14,15]$. This means that the casing soil cannot be sterile, and broad range antibiotic and antiseptic treatments cannot be used in the mushroom-growing process; consequently, $P$. tolaasii may become endemic in the casing soil and compost used in mushroom cultivation [16].

$P$. tolaasii survives well in nutrient-poor environments, such as the casing soil prior to mushroom growth, by altering the production of various enzymes, thus switching between pathogenic non-fluorescent (Smooth colony morphology on King's Medium B agar, S-type) and nonpathogenic fluorescent (Rough colony morphology, R-type) forms $[17,18]$. P. tolaasii also uses flagellarmediated chemotaxis in the wet casing soil to move towards nutrient 'signals' produced by the mushroom; once on the pileus surface, they attach and initiate disease rapidly $[5,19]$. Symptoms can appear on mushrooms at all stages of development; some apparently unaffected mushrooms also develop symptoms after harvesting, making it difficult to immediately identify and target $P$. tolaasii infections [20]. Furthermore, the pathogen is spread easily on the hands of mushroom pickers, and epidemics can occur between multiple mushroom houses [8].

Due to the adaptability and persistence of $P$. tolaasii, and the limitations on treatment options, there are very few effective methods for controlling $P$. tolaasii infection that are also safe to use on crops intended for human consumption. The current best methods of disease prevention are addition of chlorinated compounds such as calcium hypochlorite to irrigation water, and careful control of growth conditions; for example, the surface moisture of mushrooms and water level in the casing soil to minimize $P$. tolaasii chemotaxis and motility; however, the success of disease prevention is highly variable, and not guaranteed $[8,13,21]$.Other disinfectants and antibiotic compounds such as chloramine $\mathrm{T}$ and bronopol have been suggested as potential treatments [13,22], as well as natural plant extracts from Salvia miltiorrhiza [23], and the White Line Inducing Principle (WLIP) produced by Pseudomonas reactans, which reacts with tolaasin produced by P. tolaasii [24]. Other Pseudomonads that are antagonistic to $P$. tolaasii, such as Pseudomonas flourescens, have also been investigated as biocontrol strains [25]. Most recently, the application of a $P$. tolaasii-specific bacteriophage has been proposed as a novel method of controlling $P$. tolaasii infection [26], but to our knowledge none of these alternative disease prevention methods have been tested or used commercially.

The Gram-negative predatory bacterium Bdellovibrio bacteriovorus has been discussed as a potential 'living antibiotic' for bacterial pathogens of humans and animals. Bdellovibrio attach to, invade and replicate inside diverse Gram-negative bacterial prey, killing the prey cell in the process (For more detail, see $[27,28]$ ). Bdellovibrio was isolated from soil, and thus evolved to kill bacterial prey in soil and water [29]. It is highly motile in liquid, using flagellar swimming [30], and it also 'glides' slowly on solid surfaces [31], and uses chemotaxis to locate regions rich in prey [32]. Despite thus being an ideal candidate for the treatment of crop pathogens, the influence of Bdellovibrio predation on Gram-negative disease outbreaks in the soil environment remains largely unknown. The effect of Bdellovibrio on Gram-negative bacterial pathogen populations has previously been studied in live chickens and on soybean plant leaves rubbed into scratches made artificially on leaf tissue [33,34]. The supply of Bdellovibrio bacteriovorus HD100 orally to live chickens showed that, while they did reduce pathogen numbers and alter the gut microbiota, there were not any harmful effects of ingestion of Bdellovibrio, which is important in a food-related setting [33].

In this current study, we investigated whether Bdellovibrio can be used to control the soil-borne mushroom pathogen $P$. tolaasii in the natural environment of the surface of the cultivated button mushroom Agaricus bisporus post-harvest. We measured the effect of Bdellovibrio bacteriovorus HD100 application on the extent of brown blotch lesion symptoms resulting from Pseudomonas tolaasii $2192^{\mathrm{T}}$ inoculation onto mushroom pilei, and compared these with $P$. tolaasii cell counts recovered from inoculated mushrooms. We also monitored the interaction between B. bacteriovorus HD100 and $P$. tolaasii $2192^{\mathrm{T}}$ on the mushroom pileus surface to confirm Bdellovibrio predation of the pathogen in funga. Bacterial-fungal interactions have been the subject of recent reviews [35] as they involve interesting cross kingdom biology, but also affect crop productivity and thus global food security. In this study, a bacterialbacterial interaction on a fungal surface prevents a pathogenic bacterial-mushroom interaction through an active, predatory process, rather than displacement by competition, which is the first time this has been documented.

\section{Results}

Bdellovibrio inhibits $P$. tolaasii population growth in vitro To begin to test Bdellovibrio as a possible biocontrol agent against $P$. tolaasii, we first aimed to assess the impact of their co-incubation on $P$. tolaasii survival in vitro. As Figure 1 shows, The Optical Density $\left(\mathrm{OD} 600_{\mathrm{nm}}\right)$ of P. tolaasii $2192^{\mathrm{T}}$ samples in the presence 


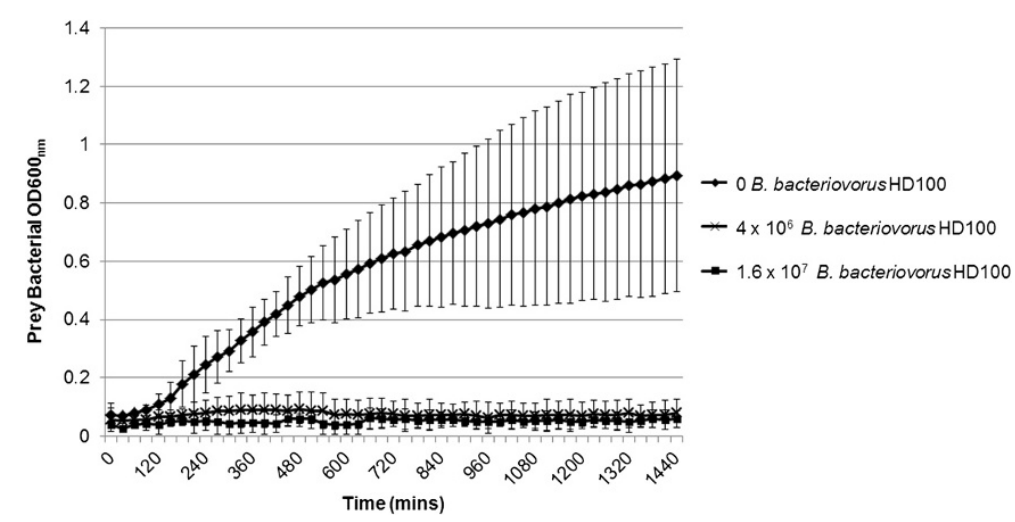

Figure 1 Reduction in P. tolaasii $\mathrm{OD} 600_{\mathrm{nm}}$ over 24 hours, in vitro, in the presence of Bdellovibrio bacteriovorus. Mean $\mathrm{OD} 600_{\mathrm{nm}}$ of P. tolaasii $2192^{\top}$ samples in the absence or presence of live B bacteriovorus HD100 added at $4 \times 10^{6}$ or $1.6 \times 10^{7}$ Plaque Forming Units $(\mathrm{PFU})(\mathrm{n}=4)$. The increase in $\mathrm{OD} 600_{\mathrm{nm}}$ in the absence of Bdellovibrio indicates $P$. tolaasii $2192^{\top}$ growth, while no increase in the presence of $4 \times 10^{6}$ or $1.6 \times 10^{7}$ B. bacteriovorus HD100 indicates inhibition of $P$. tolaasii $2192^{\top}$ growth. Error bars indicate $95 \%$ Confidence Intervals for each OD600 $\mathrm{nm}$ value.

of live B. bacteriovorus HD100 did not increase compared to a heat-killed B. bacteriovorus HD100 control, measured over 24 hours in the BMG plate-reader. (Bdellovibrio cells alone are too small to produce an $\mathrm{OD} 60_{\mathrm{nm}}$ reading). In the presence of $B$. bacteriovorus HD100 at both $4 \times 10^{6}$ cells/well and $1.6 \times 10^{7}$ cells/well, the $0 D 600_{\mathrm{nm}}$ of $P$. tolaasii $2192^{\mathrm{T}}$ did not increase from the starting value $\left(\right.$ OD600nm $=0.05,9.7 \times 10^{6} \mathrm{CFU} /$ well $)$ over 24 hours. However, when live $B$. bacteriovorus HD100 were substituted with heat-killed $B$. bacteriovorus HD100, the $\mathrm{OD} 600_{\mathrm{nm}}$ value increased from 0.08 to a final value of 0.89 , corresponding to an increase from $1.6 \times 10^{7}$ to $1.7 \times$ $10^{8}$ CFU over 24 hours, $(\mathrm{n}=3$, Figure 1$)$. This indicates that Bdellovibrio effectively suppressed the population growth of $P$. tolaasii, most likely due to killing by predation.
Brown blotch lesion intensity was reduced by Bdellovibrio application onto mushrooms

Given B. bacteriovorus HD100 was observed to suppress P. tolaasii $2192^{\mathrm{T}}$ growth in vitro, we reasoned that this effect might be replicated in a more natural environment. We first aimed to determine whether symptoms of $P$. tolaasii infection, a function of bacterial metabolism and growth, were reduced with Bdellovibrio treatment in a natural context. The intensity of lesions formed by $P$. tolaasii $2192^{\mathrm{T}}$ on the post-harvest pileus surface of the cultivated button mushroom Agaricus bisporus was measured in the presence and absence of B. bacteriovorus HD100, as shown in Figure 2. Mushroom pilei inoculated with $P$. tolaasii $2192^{\mathrm{T}}$ alone, in the absence of any treatment with B. bacteriovorus HD100, formed dark, wet surface lesions, the primary symptom of

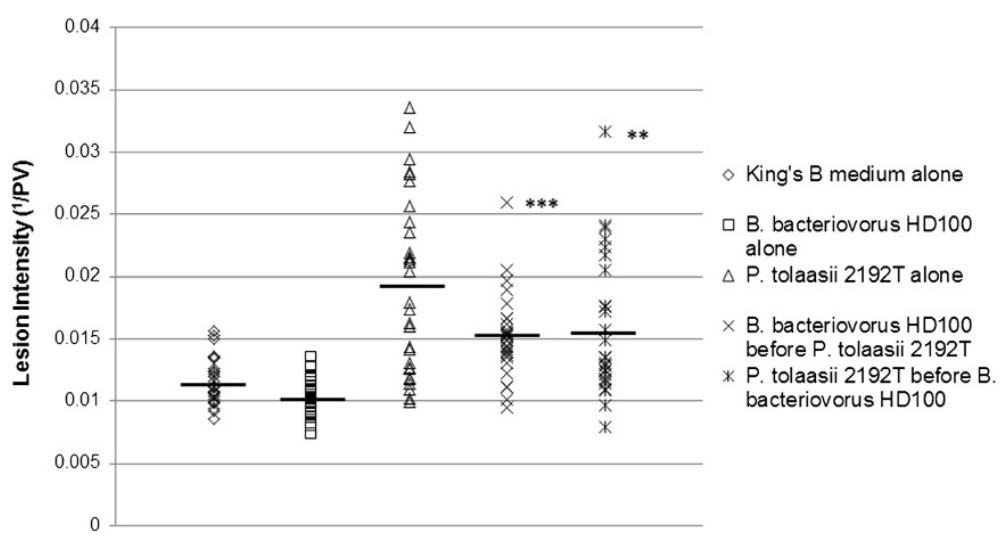

Figure 2 Lesion intensity on P. tolaasii-inoculated mushrooms in the presence and absence of Bdellovibrio. Lesion intensities on mushroom pilei under 5 different treatment conditions, detailed to the right of the graph. Each $P$ tolaasii $2192^{\top}$ inoculation contained $1.7 \times 10^{6} \mathrm{CFU}$, and each B. bacteriovorus HD100 inoculation contained $2.9 \times 10^{6} \mathrm{PFU}$. Higher lesion intensity indicates a greater level of brown blotch disease symptoms and therefore a higher level of $P$. tolaasii infection. Horizontal black bars indicate the mean lesion intensity value for each treatment group. Student's t-test of significance between B. bacteriovorus HD100 treated and non-treated mushrooms inoculated with P. tolaasii $2192^{\top}:{ }^{* *} p<0.01,{ }^{* * *} p<0.001$. 
brown blotch disease, after 48 hours at $29^{\circ} \mathrm{C}$ (mean intensity $=0.019^{1} / \mathrm{PV} \pm 0.0005, \mathrm{n}=30$ ). In contrast, pilei treated with a King's Medium B control (the preferred growth medium of $P$. tolaasii) did not form these dark lesions (mean intensity $=0.012^{1} / \mathrm{PV} \pm 0.0005, \mathrm{n}=30$ ); similarly, those treated with $B$. bacteriovorus HD100 alone, and not inoculated with $P$. tolaasii $2192^{\mathrm{T}}$, also did not form dark lesions (mean intensity $=0.010^{1} / \mathrm{PV} \pm 0.0005$, $\mathrm{n}=30$ ), so Bdellovibrio application itself did not have a significant adverse effect on the appearance of mushroom pilei.

Post-harvest mushrooms treated with $B$. bacteriovorus HD100 either 30 minutes before or 30 minutes after P. tolaasii $2192^{\mathrm{T}}$ inoculation developed significantly lighter lesions than those inoculated with $P$. tolaasii $2192^{\mathrm{T}}$ alone (average intensity $=0.015$ and $0.0161 / \mathrm{PV} \pm$ 0.0005 respectively, $\mathrm{n}=30$ in both cases, vs. $0.0191 / \mathrm{PV} \pm$ 0.0005 for mushrooms inoculated with P. tolaasii $2192^{\mathrm{T}}$ alone). This demonstrates that Bdellovibrio effectively reduces the dark lesions of brown blotch disease caused by $P$. tolaasii, and that this reduction is slightly greater where Bdellovibrio is added before $P$. tolaasii. The significance of the difference in lesion intensities between B. bacteriovorus HD100 treated and untreated, P. tolaasii $2192^{\mathrm{T}}$ inoculated mushrooms was greater when Bdellovibrio was added before P. tolaasii $2192^{\mathrm{T}}$ than when added after (Student's t-test $\mathrm{p}<0.001$ for B. bacteriovorus HD100 added before $P$. tolaasii $2192^{\mathrm{T}}$ vs. $P$. tolaasii $2192^{\mathrm{T}}$ alone, $\mathrm{p}<0.01$ for $B$. bacteriovorus HD100 added after P. tolaasii $2192^{\mathrm{T}}$ vs. P. tolaasii $2192^{\mathrm{T}}$ alone). Bdellovibrio application may therefore be more effective as a preventative measure to protect mushrooms against brown blotch disease, rather than a treatment for an already infected mushroom crop, and could be explored as a background addition to mushroom compost or casing layers to maintain "health".

\section{Scanning Electron Microscope images show}

\section{$B$. bacteriovorus attachment and bdelloplast formation} in $P$. tolaasii cells

To confirm whether the reduction in P. tolaasii $2192^{\mathrm{T}}$ numbers and brown blotch lesion intensity was due to B. bacteriovorus HD100 predation in funga or another competition for resources, the interaction between $P$. tolaasii and Bdellovibrio was monitored in samples from the surface of the post-harvest $A$. bisporus (shown untreated in Figure 3a), 48 hours after mushroom treatments, using Scanning Electron Microscopy (SEM). P. tolaasii $2192^{\mathrm{T}}$ added alone to the mushroom pileus accumulated together, in an arrangement parallel to the pileus surface, in the pits present between chitin fibres (Figure 3b). Fibrillar structures attached to the $P$. tolaasii $2192^{\mathrm{T}}$ cells were frequently observed, which have also been documented in previous microscopic studies [36]. These resemble pili, with extracellular polymeric substances laid down on them, and may allow P. tolaasii to adhere tightly to the mushroom surface and to each other in a biofilm, to rapidly initiate disease (Figure 3b [37]). B. bacteriovorus HD100 added alone to the mushroom surface survived after 48 hours and also accumulated in the small pits between chitin fibres (Figure 3c).

Where B. bacteriovorus HD100 was added to the mushroom surface both before (Figure $3 \mathrm{e}$ ) and after $P$. tolaasii $2192^{\mathrm{T}}$ (Figure 3d), B. bacteriovorus HD100 attachment to P. tolaasii $2192^{\mathrm{T}}$ cells was observed: a crucial first step in the predatory process. In addition, bdelloplasts, the rounded, dead P. tolaasii structures in which Bdellovibrio establish, grow and replicate after attachment and invasion, were also observed where $B$. bacteriovorus HD100 was added before or after P. tolaasii $2192^{\mathrm{T}}$. Although a valid statistical survey is not possible in these SEM samples, bdelloplasts were most clearly visible on the mushroom surface where B. bacteriovorus HD100 was added before $P$. tolaasii $2192^{\mathrm{T}}$ (Figure $3 \mathrm{~d}$ ). This correlates with the greater reduction in lesion intensity measurements on mushrooms where B. bacteriovorus HD100 was added before P. tolaasii $2192^{\mathrm{T}}$ (Figure 2): Bdellovibrio attachment to prey and subsequent bdelloplast formation may be easier, and occur more rapidly, where $P$. tolaasii cells have not had time to accumulate, adapt and adhere to the mushroom surface, preventing $P$. tolaasii from producing as much tolaasin, and thus reducing the extent of the characteristic brown blotch symptoms.

A King's Medium B control addition to the pileus resulted in the growth of different types of bacterial cells, with different morphologies that were distinct from that of P. tolaasii $2192^{\mathrm{T}}$ \& B. bacteriovorus HD100 (Figure 3f); however, typically, no bacterial cells were observed on untreated mushroom tissue (Figure 3a). This indicates that the supermarket mushrooms carry a small, indigenous bacterial microflora that replicates readily in added growth medium, which may impact upon $P$. tolaasii CFU numbers recovered from experimentally inoculated tissue, as described below.

\section{Application of Bdellovibrio before inoculation with $P$. tolaasii reduced the number of $P$. tolaasii in infected mushroom tissue}

To determine whether the reduction in lesion intensity after treatment with $B$. bacteriovorus HD100 correlated with a reduction in $P$. tolaasii $2192^{\mathrm{T}}$ cell numbers, CFU were recovered and enumerated from mushroom tissue that had been inoculated with $P$. tolaasii $2192^{\mathrm{T}}$ and pre-treated with $B$. bacteriovorus HD100, compared with a $P$. tolaasii $2192^{\mathrm{T}}$ inoculated, non-B. bacteriovorus HD100 treated control (Figure 4). A mean number of $4.5 \times 10^{7}$ and $3.9 \times 10^{7} \mathrm{CFU}$ were recovered from mushrooms pre-treated with $2.9 \times 10^{6}$ or $1.4 \times 10^{7}$ 
a

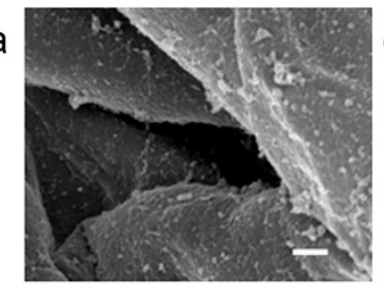

b
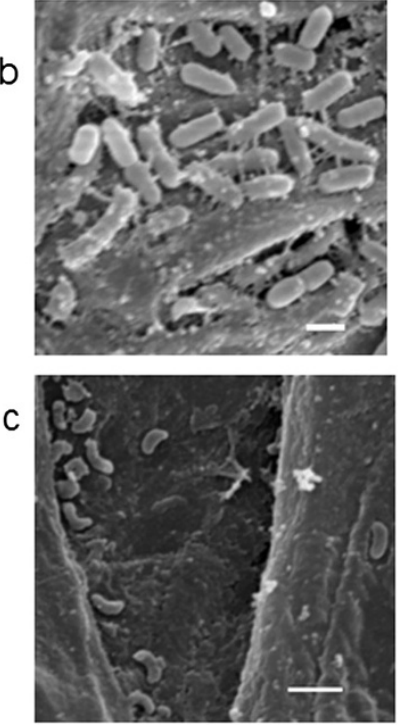

e

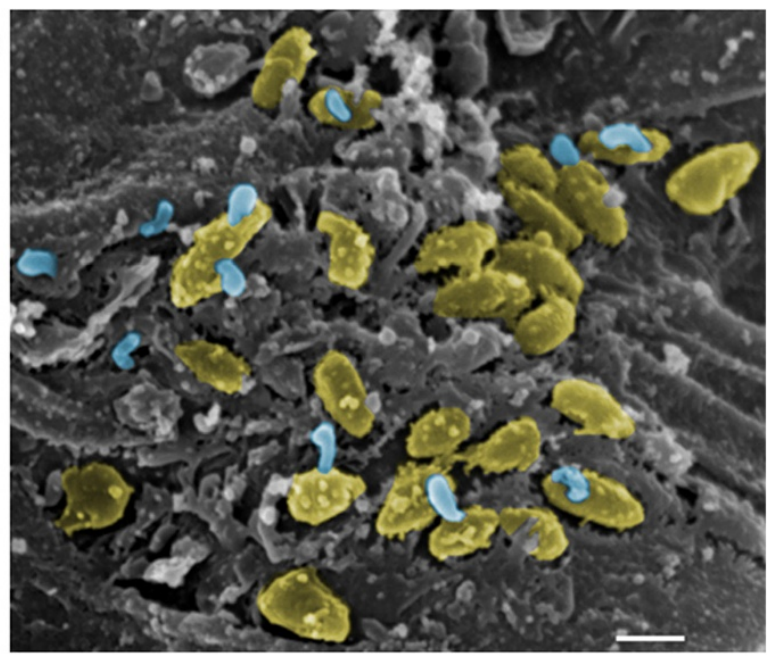

d

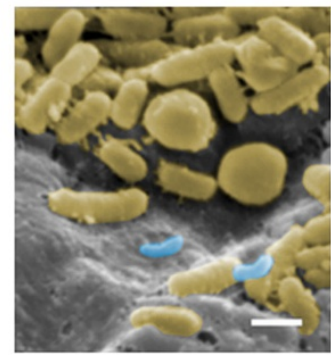

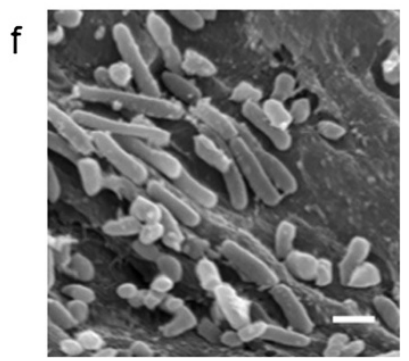

Figure 3 Predatory interactions between Bdellovibrio and P. tolaasii "in funga" on the mushroom pileus surface. Scanning Electron Microscope images showing the mushroom pileus surface 48 hours after the following treatments: $\mathbf{a}$. untreated mushroom pileus surface b. inoculation of $P$. tolaasii $2192^{\top}$ alone $\mathbf{c}$. Inoculation of B. bacteriovorus HD100 alone $\mathbf{d}$. and e. Co-inoculation of $P$. tolaasii $2192^{\top}$ and B. bacteriovorus HD100 and f. Application of King's medium B alone. In image e, B. bacteriovorus HD100 (blue) are shown attached at one pole to $P$. tolaasii $2192^{\top}$ (yellow), a crucial first step in the predatory process. Images $\mathbf{d}$ and e both show rounded P. tolaasii $2192^{\top}$ cells, characteristic of the bdelloplast structures formed after Bdellovibrio invades the host cell and begins replication. $1 \mu \mathrm{m}$ scale bar shown.

PFU live B. bacteriovorus HD100 respectively, which were both significantly lower than the mean $1.9 \times 10^{8} \mathrm{CFU}$ recovered from mushrooms inoculated with $P$. tolaasii $2192^{\mathrm{T}}$ alone (Student's t-test of difference $\mathrm{p}<0.05$ ); these observations correlated with a significant reduction in lesion intensity $(\mathrm{p}<0.001)$ on mushrooms treated with $2.9 \times 10^{6}$ and $1.4 \times 10^{7}$ PFU B. bacteriovorus HD100 (mean $=0.010^{1} / \mathrm{PV}$ in both cases) compared with mushrooms inoculated with $P$. tolaasii $2192^{\mathrm{T}}$ alone $\left(\right.$ mean $\left.=0.014^{1} / \mathrm{PV}\right)$. Despite this significant reduction in lesion intensity, the total number of CFU recovered from B. bacteriovorus HD100 treated mushrooms onto King's Medium B was high, suggesting that the bacteria recovered from seemingly similar, beige-coloured colonies on the King's Medium B plates were not solely pathogenic P. tolaasii $2192^{\mathrm{T}}$, but might include other species indigenous to the mushroom pileus surface that are not well preyed upon by B. bacteriovorus HD100, as observed in SEM images of mushroom tissue to which King's medium $B$ broth was added alone.
Enterobacter species are present on the surface of some commercially produced supermarket mushrooms

The number of CFU recovered from the mushrooms that were treated with $B$. bacteriovorus HD100 after inoculation with $P$. tolaasii was relatively high compared to mushrooms inoculated with $P$. tolaasii alone. To confirm the identity of the bacteria seen in Figures $3 \mathrm{~d}$ and e and recovered from supermarket mushroom tissue pretreated with $B$. bacteriovorus $\mathrm{HD} 100$ before $P$. tolaasii $2192^{\mathrm{T}}$ at both $2.9 \times 10^{6}$ and $1.4 \times 10^{7} \mathrm{PFU} \mathrm{ml}^{-1}, 20 \mathrm{col}-$ onies taken from the King's medium B agar plates used to enumerate bacterial CFU, recovered from the treated mushroom tissue of two mushrooms in each group, were grown on Coliform Chromogenic agar (oxoid). This agar contains two chromogenic substrates that turn purple when cleaved by the enzymes glucorinidase and galactosidase, which are both present in coliforms such as E. coli, and absent from Pseudomonads (including P. tolaasii); all 20 colonies were pigmented purple indicating them as coliform, closely related to E. coli, and therefore as indigenous species to the mushroom 


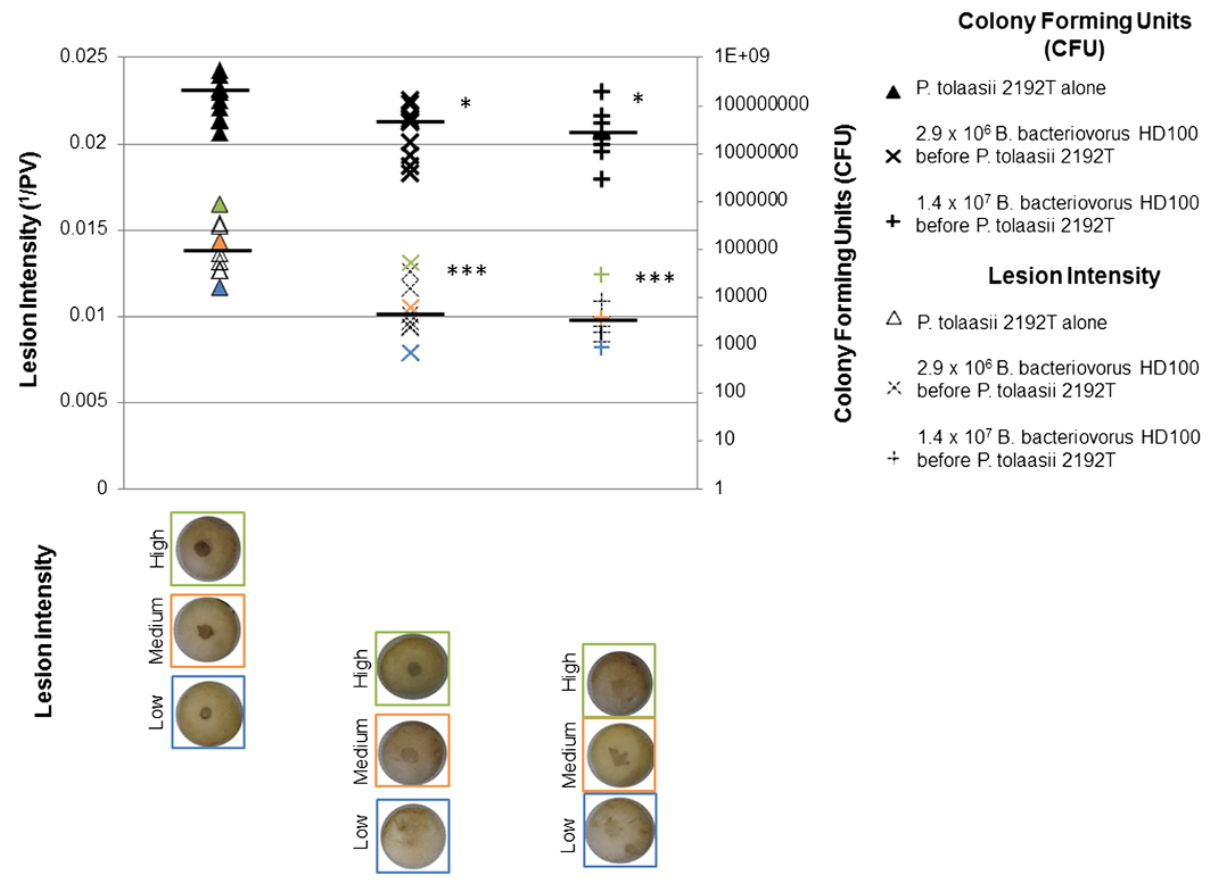

Figure 4 Bacterial CFU numbers recovered from P. tolaasii-inoculated mushrooms in the presence and absence of Bdellovibrio. Lesion intensities and number of bacterial colony forming units (CFU) recovered from mushroom pilei subject to three different treatments detailed to the right. Each P. tolaasii $2192^{\top}$ inoculation contained $1.7 \times 10^{6} \mathrm{CFU}$. Images of mushrooms with typical: high, mean, and low intensity lesions in each group are shown below the graph. Horizontal black bars indicate the mean values for lesion intensity/CFU count in each treatment group. Student's t-test of significance between B .bacteriovorus-treated and non-treated mushrooms inoculated with P. tolaasii $2192^{\top}$ : ${ }^{*} p<0.05$, ***p $<0.001$.

pileus, and distinctly different to $P$. tolaasii $2192^{\mathrm{T}}$, which produced straw coloured colonies on the agar. Three of these coliform isolates were identified by $16 \mathrm{~s}$ rDNA sequencing as members of the Enterobacter genus using the BLAST online tool (http://blast.ncbi.nlm.nih.gov/Blast. cgi), which showed that the isolates were most closely related to Enterobacter sp. LB9 (GenBank: JQ864377.1) matching 99\% identity. This explains the relatively high number of total bacterial colonies recovered from mushroom tissue treated with Bdellovibrio, despite the reduction in the dark lesions characteristic of P. tolaasii infection: Bdellovibrio predation rapidly reduces $P$. tolaasii population numbers on the mushroom surface, but does not necessarily reduce those of other non-disease causing, likely mushroom-indigenous species, such as the Enterobacter isolated in this study. The King's Medium B in which P. tolaasii $2192^{\mathrm{T}}$ and B. bacteriovorus HD100 were added to the surface of the mushroom during test inoculations, and the cell-lysate debris left behind after $P$. tolaasii death due to predation, may then allow these indigenous Enterobacter to occupy the niche caused by Bdellovibrio predation of $P$. tolaasii.

\section{Discussion}

We showed that B. bacteriovorus HD100 is a predator of P. tolaasii $2192^{\mathrm{T}}$ in vitro and in vivo (in funga), suppressing population growth of the strain over a 24-hour period where $4 \times 10^{6}$ or $1.6 \times 10^{7}$ PFU B. bacteriovorus HD100 were added to pathogen on post-harvest mushrooms (Figures 1 and 4). P. tolaasii is a difficult pathogen to control in mushroom grow-houses due to its ability to persist in nutrient-poor soils and the ease with which it spreads through mushroom compost, through flagellar swimming, and via the hands of pickers during the manual harvesting process [8]. Furthermore, commensal bacterial species in the mushroom casing soil play a key role in mushroom growth initiation, and therefore any treatment to prevent or treat $P$. tolaasii infection must not result in a completely sterile growth environment, which may result from broad antibiotic or antiseptic treatment. Thus it is beneficial to explore post-harvest anti- $P$. tolaasii treatments, such as this study with $B$. bacteriovorus.

Our SEM images confirmed that B. bacteriovorus HD100 survived on the post-harvest supermarket mushroom surfaces after 48 hours, and was therefore unaffected by any pre-treatment of those mushrooms for commercial purposes to promote growth and extend shelf-life in the film-covered plastic trays they were sold in (Figure 3c). $B$. bacteriovorus is therefore a viable treatment for bacterial diseases of mushrooms, such as brown blotch disease. Previous studies of mushroom infections have found that a 'threshold' number of $P$. tolaasii cells are required for 
the initiation of infection, which includes production of tolaasin, the chemical mediator of the brown blotch symptom development [8]. We found that when B. bacteriovorus HD100 was applied to the surface of post-harvest, commercially grown mushrooms before or after inoculation with $P$. tolaasii, both the intensity of the brown blotch symptoms of disease and the number of $P$. tolaasii $2192^{\mathrm{T}}$ present the mushroom surface were significantly reduced (Figures 2 and 4), supporting the threshold hypothesis. Our SEM images also showed that B. bacteriovorus HD100 attached to, invaded and killed $P$. tolaasii $2192^{\mathrm{T}}$ cells by forming bdelloplasts on the pileus surface, when added both before or after P. tolaasii $2192^{\mathrm{T}}$ inoculation (Figure 3d and e); thus, reduction in $P$. tolaasii $2192^{\mathrm{T}}$ numbers and disease symptoms was due to predatory activity by $B$. bacteriovorus HD100. As the consumer preference is for white, clean-looking mushrooms with minimal surface damage, the reduction in brown blotch tissue damage by $B$. bacteriovorus application could increase the yield and possibly the shelf life of high-quality, marketable mushrooms. This study investigated the survival of $B$. bacteriovorus HD100 and its predatory activity against $P$. tolaasii on the surface of post-harvest mushrooms up to 48 hours, sufficient time for brown blotch disease to develop on untreated mushrooms. Thus studies over longer time points, covering time from transportation to the sell-by date, would need to be investigated, in future work, if Bdellovibrio was to be applied as a treatment to extend shelf-life.

In addition to reducing the population of $P$. tolaasii on the mushroom surface, Bdellovibrio are natural soil dwellers and so their application to casing soil could also prevent spread of brown blotch between mushrooms in the growth environment and between grow houses. In this way, the fast swimming motility of Bdellovibrio [38] would allow efficient location of $P$. tolaasii prey, using chemotaxis, in the wet casing soil prior to mushroom growth initiation, and translocation by gliding along the mushroom pileus surface after mushroom fruiting bodies have formed, preventing $P$. tolaasii infection establishment at multiple stages of mushroom growth; previously, the possibility of infection throughout the mushroom growth period has been an obstacle in brown blotch disease control. Further pre-harvest studies could investigate the longevity and protective effect of Bdellovibrio inoculated into the casing soil around mushroom mycelium, before and after fruiting body initiation, on growing A. bisporus. As Bdellovibrio preys efficiently upon some, but not all, species of Pseudomonas (unpublished observations), and some Pseudomonads in the casing soil such as P. putida are important in fruiting body initiation; further studies would additionally investigate the predatory activity of $B$. bacteriovorus HD100 against such commensal strains in vitro and in the casing soil to ensure that there are no effects that would have an adverse impact on mushroom fruiting body production.

As host-dependent Bdellovibrio require prey cells to survive, the post-harvest treatment could also be selflimiting, as Bdellovibrio would die once P. tolaasii prey had been eradicated; further studies could quantify this. Furthermore, these in vitro and in vivo predation studies suggest that $B$. bacteriovorus may be able to survive the action of the toxins produced by $P$. tolaasii and other members of the Pseudomonas genus, including tolaasin and other lipases and peptidases, which cause the damage to the mushroom pileus [39]. This suggests that Bdellovibrio species may be effective against other crop pathogenic bacterial species, even if they produce biologically active secreted compounds. This could be followed up with studies of the pure compounds themselves versus B. bacteriovorus.

We infrequently isolated Enterobacter species in our experiments from supermarket mushrooms, likely being commensals growing in number after pre-treatment with B. bacteriovorus HD100, suggesting that these Enterobacter isolates are not susceptible to Bdellovibrio predation. A Plant Growth Promoting (PGP) Enterobacter species, Enterobacter cloacae, has been described previously, which colonises rice root surfaces and competes with other species in the soil microbiota for nutrients [40]. Enterobacter species have also previously been isolated from spent mushroom compost [41], where they might associate with the mushroom surface in a similar way, competing with other mushroom-indigenous bacteria as commensal species. As Bdellovibrio has previously been shown to prey upon diverse Enterobacter species [42], it was unexpected that numbers seemed unaffected by Bdellovibrio predation; inhibition of predation in this case may be due to a factor such as the presence of a protective S-layer, which may prevent Bdellovibrio from attaching to and invading Enterobacter prey cells [43], but confirming S-layer presence was beyond the scope of this study. The Enterobacter species in this study were isolated from Bdellovibriotreated mushroom tissue, unaffected by any brown blotch disease symptoms; and so the species are unlikely to be pathogenic, and may be commensals. It could therefore be beneficial that Bdellovibrio are unable to prey upon the Enterobacter species isolated in this study, preserving any beneficial commensal effect they might have, while still protecting against $P$. tolaasii infection.

\section{Conclusions}

Bdellovibrio bacteriovorus HD100 are terrestrial bacteria which show natural control of Pseudomonas tolaasii, a spoilage pathogen of mushroom crops, on the non-sterile, biotic surface of the mushroom pileus. These terrestrial bacteria therefore have a natural ability 
to act as "food security guards" against Gram-negative crop pathogens.

\section{Methods}

The bacterial strains and primers used in this study are listed in Tables 1 and 2, respectively.

\section{Bacterial culturing procedures}

E. coli S17-1 was grown in YT medium (5 g/L Sodium Chloride, $5 \mathrm{~g} / \mathrm{L}$ Peptone, $8 \mathrm{~g} / \mathrm{L}$ Tryptone, $\mathrm{pH}$ 7.5) shaken at $200 \mathrm{rpm}$ at $37^{\circ} \mathrm{C}$ for 16 hours. The predatory, hostdependent $B$. bacteriovorus HD100 was cultured at $29^{\circ} \mathrm{C}$ on E. coli S17-1 prey cells on YPSC medium agar (0.125 g/L Magnesium Sulphate, $0.25 \mathrm{~g} / \mathrm{L}$ Sodium Acetate, $0.5 \mathrm{~g} / \mathrm{L}$ Bacto Peptone, $0.5 \mathrm{~g} / \mathrm{L}$ Yeast Extract, $0.25 \mathrm{~g} / \mathrm{L}$ Calcium Chloride Dihydrate, $\mathrm{pH}$ 7.6) using an overlay plate technique. Liquid predatory cultures of $B$. bacteriovorus HD100 for predation tests were produced by 16 hour incubation at $29^{\circ} \mathrm{C}$ in $2 \mathrm{mM} \mathrm{CaCl}_{2} 25 \mathrm{mM}$ HEPES pH 7.6 buffer, containing E. coli S17-1 prey, both methods described in detail elsewhere [30]. Following growth the $B$. bacteriovorus HD100 were filtered by passage twice through Millipore $0.45 \mu \mathrm{m}$ syringe filters to remove any remaining prey. P. tolaasii $2192^{\mathrm{T}}$ was grown in King's Medium B (Prepared using Scientific Laboratory Supplies Bacto ${ }^{\mathrm{mm}}$ Proteose Peptone No. 3, product code 221693, according to the UNE-EN 12780 standard protocol, Cat. No. 1154) at $29^{\circ} \mathrm{C}$ for 16 hours. When isolating indigenous bacteria from mushrooms Coliform chromogenic agar (Oxoid, product code CM0956) was used, again with incubation at $29^{\circ} \mathrm{C}$.

\section{B. bacteriovorus predation of $P$. tolaasii populations grown in vitro}

$B$. bacteriovorus predation of $P$. tolaasii was firstly tested in a buffer-Pseudomonas King's medium B suspension in a plate reader. $180 \mu \mathrm{l} /$ well of a $50 \% \mathrm{v} / \mathrm{v}$ King's Medium B, 50\% v/v $2 \mathrm{mM} \mathrm{CaCl}_{2} 25 \mathrm{mM}$ HEPES pH 7.6 buffer mixture was added to the wells of a clear-bottomed, 96well Krystal microplate (Porvair Sciences Ltd, Product No. 215006). $1.5 \mathrm{ml}$ aliquots of predatory cultures of $B$. bacteriovorus HD100, containing $2.5 \times 10^{8} \mathrm{PFU} \mathrm{m}{ }^{-1}$, were prepared and heat killed at $105^{\circ} \mathrm{C}$ for 5 minutes and allowed to cool to ambient temperature $\left(21^{\circ} \mathrm{C}\right)$. This heat-killed, cooled culture was then added, in a 3:1 ratio, to a live liquid culture of $B$. bacteriovorus HD100 to give $6.3 \times 10^{7} \mathrm{PFU} \mathrm{m} \mathrm{m}^{-1}$ of live B. bacteriovorus HD100. This was used as a diluted application of Bdellovibrio to achieve a lowered concentration of predator in our experiments. Microplate wells were then set up using either $64 \mu \mathrm{l}$ of the heat-killed culture alone as a negative control; $64 \mu \mathrm{l}$ of the heat-killed/live mixture described above; or $64 \mu \mathrm{l}$ of the original live culture of Bdellovibrio. These preparations gave final live B. bacteriovorus HD100 cell numbers of $0,4 \times 10^{6}$ or $1.6 \times 10^{7} \mathrm{PFU}$, respectively. For test prey cells, a liquid culture of P. tolaasii $2192^{\mathrm{T}}$, containing $7.4 \times 10^{8} \mathrm{CFU} / \mathrm{ml}^{-1}$, was diluted 2 in 5 to give $3.0 \times 10^{8} \mathrm{CFU} / \mathrm{ml}^{-1}$ in $50 \% \mathrm{v} / \mathrm{v}$ King's Medium B, $50 \% \mathrm{v} / \mathrm{v}$ $2 \mathrm{mM} \mathrm{CaCl}_{2} 25 \mathrm{mM}$ HEPES pH 7.6 buffer mixture. $20 \mu \mathrm{l}$ of this diluted P. tolaasii $2192^{\mathrm{T}}$ containing $5.9 \times 10^{6} \mathrm{CFU}$ was transferred to the microplates containing the predator mixtures. The plates were then sealed with a Breatheasy ${ }^{\circ}$ seal (Diversified Biotech Cat. No. BEM-1) and transferred to a BMG plate reader programmed to incubate and measure the $\mathrm{OD}^{\mathrm{T}} 00_{\mathrm{nm}}$ of each well, as an indicator of P. tolaasii $2192^{\mathrm{T}}$ growth, immediately, and then every 30 minutes for 24 hours. B. bacteriovorus HD100 alone does not produce an $\mathrm{OD} 600_{\mathrm{nm}}$ value due to its small cell size [48].

\section{Testing the effect of $B$. bacteriovorus predation of $P$. tolaasii on brown blotch lesion intensity on infected} mushrooms

Button mushrooms (Agaricus bisporus) used in this experiment were sourced from a supermarket and thus were from a non-sterile setting. Wearing gloves to avoid hand contamination, mushrooms were gently wiped clean with laboratory tissue to remove any attached compost and excess surface moisture, but allow the mushroom epidermis to remain intact. Stipes were trimmed flat with a sterile scalpel blade, and each mushroom was placed, pileus side up, in a sterile $50 \mathrm{ml}$ skirted Falcon tube. Bacterial preparations were grown in liquid culture as before, but concentrated before use, by centrifugation in Falcon tubes at $5200 \mathrm{rpm}, 20 \mathrm{~min}$ at $25^{\circ} \mathrm{C}$ in a Sigma $4 \mathrm{~K} 15$ centrifuge and resuspension in King's Medium B to the appropriate concentration (which was checked by viable counting after the experiments). (The P. tolaasii $2192^{\mathrm{T}}$ produced only beige smooth colonies on the King's Medium B, after 24 hour incubation at $29^{\circ} \mathrm{C}$.) Concentrations used in the $15 \mu \mathrm{l}$ applications to the mushrooms were as follows:

Table 1 Bacterial strains used in this study

\begin{tabular}{lll}
\hline Strain & Description & Reference \\
\hline Escherichia coli S17-1 (used as prey to initially culture Bdellovibrio) & thi, pro, hsdR ${ }^{-}, h s d M^{+}$, recA, integrated plasmid RP4-Tc::Mu-Kn::Tn7 & [44] \\
Bdellovibrio bacteriovorus HD100 & Type strain, genome sequenced & [29,45] \\
Pseudomonas tolaasii $2192^{\top}$ & $\begin{array}{l}\text { Type strain, NCPPB No. 2192 }{ }^{\top} \text {, brown blotch pathogen of mushrooms, [46] } \\
\text { acquired from RW Jackson (University of Reading) }\end{array}$ \\
\hline
\end{tabular}


Table 2 Primers used in this study

\begin{tabular}{lll}
\hline Name & Sequence & Description \\
\hline 16 s_8F & AGAGTTTGATCMTGGC & 'Universal' forward primer designed to amplify/sequence diverse bacterial 16 s rDNA sequences [47] \\
16 s_1492rev & TACCTTGTTAYGACTT & 'Universal' reverse primer designed to amplify/sequence diverse bacterial 16 s rDNA sequences [47] \\
\hline
\end{tabular}

P. tolaasii $2192^{\mathrm{T}}\left(1.7 \times 10^{6}\right.$ Colony Forming Units, CFU, $\left.15 \mathrm{\mu l}^{-1}\right)$, B. bacteriovorus HD100 $\left(2.9 \times 10^{6}\right.$ PlaqueForming Units, PFU, $15 \mathrm{\mu l}^{-1}$ ) and King's Medium B were applied directly to the mushroom pileus in one of 5 pairwise combinations for the experiment in Figure 2 (see Table 3 below). In later experiments other concentrations of bacteria were used as described.

Mushrooms were incubated statically at $29^{\circ} \mathrm{C}$, in capped Falcon tubes for 48 hours, after which brown blotch lesions appeared on P. tolaasii $2192^{\mathrm{T}}$ infected samples. Lesions were photographed using a Canon PowerShot A620 digital camera and tripod in a containment hood, with the same standard lighting for each photograph. The aperture was set to $F=5.6$ and shutter speed was set to $1 / 60 \mathrm{sec}$, to give a good light exposure ( \pm 0 Exposure Value units). The lesion intensity on each mushroom was analysed using ImageJ analysis software (http://rsbweb.nih.gov/ij/): Image J converted each image to 8 -bit grayscale, assigning a value of 0-255 to each pixel; the area of mushroom inoculated was selected and the average grayscale value for each pixel (the Pixel Value, PV), was calculated. On this scale, $0=$ black and $255=$ white, and so the data were transformed using the formula $1 / \mathrm{PV}$ to invert the scale, so that darker lesions give higher intensity values. These transformed data are displayed in Figures 2 and 4.

\section{Visualising $B$. bacteriovorus and $P$. tolaasii interactions on the mushroom surface}

Mushrooms under each of the five treatment conditions detailed in Table 3 were visualised using Scanning Electron Microscopy. Preparation of mushroom samples for imaging was as follows: Samples of mushroom pileus surface tissue W $5 \mathrm{~mm} \times \mathrm{L} 5 \mathrm{~mm} \times \mathrm{D} 2 \mathrm{~mm}$ were cut and stored in $70 \%$ ethanol. They were then dehydrated through a graded series of ethanol concentrations (fresh $70 \%$ ethanol, followed by $90 \%$ ethanol, and finally 2 changes of $100 \%$ ethanol) and dried using a Polaron E3000 Critical
Point Dryer. The dried samples were mounted onto aluminium stubs using silver paint, and the stubs were gold coated ( 10 $\mu \mathrm{m}$ thickness) using a Polaron E5100 SEM Coating Unit. The samples were viewed and photographed under a JEOL JSM 840 Scanning Electron Microscope at $20 \mathrm{kV}$. Images were false-coloured in Adobe Photoshop by selecting $P$. tolaasii $2192^{\mathrm{T}}$ and B. bacteriovorus HD100 cells and using the 'Colorize' function in the 'Hue/Saturation' tool. A pale yellow colour was selected for $P$. tolaasii to provide optimum contrast to the mushroom surface, and blue gave a sharp contrast for the B. bacteriovorus.

\section{Enumerating $P$. tolaasii recovered from infected mushroom tissue}

Mushrooms were pre-treated using methods as above; B. bacteriovorus HD100 was applied at either $2.9 \times 10^{6}$ or $1.4 \times 10^{7}$ PFU $15 \mu \mathrm{l}^{-1}$ before $1.7 \times 10^{6}$ P. tolaasii $2192^{\mathrm{T}}$ in $15 \mu$ l. Mushroom lesions were photographed in a class II containment hood after 48 hours, as above, and lesion intensities were analysed using ImageJ analysis software. Lesion tissue from each mushroom was then cut out using a sterile scalpel blade. Tissue samples were weighed and homogenised in sterile $2 \mathrm{mM} \mathrm{CaCl}_{2} 25 \mathrm{mM}$ HEPES pH 7.6 buffer ( $1 \mathrm{ml}$ Calcium HEPES/0.04 g lesion tissue) using separate glass pestle and mortar sets, (pre-cleaned with ethanol and dried), for samples under each of the different treatment combinations. P. tolaasii $2192^{\mathrm{T}} \mathrm{CFU}$ recovered from each sample were enumerated by serial dilution and plating on King's Medium B agar, incubated at $29^{\circ} \mathrm{C}$ for 15 hours. Characteristic smooth, beige colonies growing on King's Medium B were counted and recorded as P. tolaasii.

\section{Identifying bacterial species co-isolated from some experimentally infected supermarket mushroom tissue} When King's Medium B plates were examined and counted to enumerate P. tolaasii $2192^{\mathrm{T}}$ from one batch

Table 3 Treatment conditions applied to mushroom pilei

\begin{tabular}{|c|c|c|c|c|}
\hline Condition & Addition 1 (in $15 \mu \mathrm{l}$ ) & $30 \mathrm{~min}, 21^{\circ} \mathrm{C}$ & Addition 2 (in $15 \mu \mathrm{l}$ ) & $48 \mathrm{~h}, 29^{\circ} \mathrm{C}$ \\
\hline King's Medium B control & King's Medium B broth & $\rightarrow$ & King's Medium B broth & $\rightarrow$ \\
\hline B. bacteriovorus alone & B. bacteriovorus HD100 & $\rightarrow$ & King's Medium B broth & $\rightarrow$ \\
\hline P. tolaasii alone & P. tolaasii $2192^{\top}$ & $\rightarrow$ & King's Medium B broth & $\rightarrow$ \\
\hline B. bacteriovorus before $P$. tolaasii & B. bacteriovorus HD100 & $\rightarrow$ & P. tolaasii $2192^{\top}$ & $\rightarrow$ \\
\hline B. bacteriovorus after $P$. tolaasii & P. tolaasii $2192^{\top}$ & $\rightarrow$ & B. bacteriovorus HD100 & $\rightarrow$ \\
\hline
\end{tabular}

Details of the 5 pairwise combinations of B. bacteriovorus HD100, P. tolaasii $2192^{\top}$ and King's Medium B added to Agaricus bisporus mushrooms to test the effect of $B$. bacteriovorus predation of $P$. tolaasii on affected mushroom brown blotch lesion intensity. 
of six mushrooms (two in each treatment group), a relatively high number of bacterial colonies, some of which were small and clumped together on the King's B medium enumeration plates, were recovered from $P$. tolaasii $2192^{\mathrm{T}}$ inoculated mushroom tissue pre-treated with $B$. bacteriovorus HD100 compared with tissue inoculated with $P$. tolaasii $2192^{\mathrm{T}}$ alone. This suggested that other, possibly indigenous, bacteria were present, in addition to the added P. tolaasii $2192^{\mathrm{T}}$ and B. bacteriovorus HD100. To test this, 20 single colonies were selected from the small clumped colonies recovered from mushroom tissue pre-treated with B. bacteriovorus HD100 at both $2.9 \times 10^{6}$ and $1.4 \times 10^{7} \mathrm{PFU} \mathrm{m}{ }^{-1}$ (taken from two mushrooms from each group). These were plated directly onto Coliform chromogenic agar (CCA) (Oxoid) and incubated at $29^{\circ} \mathrm{C}$ for 15 hours, along with a P. tolaasii $2192^{\mathrm{T}}$ control, to distinguish between Pseudomonads and Coliforms. All of these small, clumped colonies were purple on CCA, indicating a different identity to $P$. tolaasii $2192^{\mathrm{T}}$, which gave straw-coloured colonies on CCA. Total genomic DNA from each of 3 purple coliform isolates (hereafter referred to as Supermarket Mushroom Isolates 1, 2 and 3) was extracted using a Sigma DNA extraction kit and 'universal' $16 \mathrm{~s}$ ribosomal DNA primers (Table 2) were used in PCR reactions to amplify $16 \mathrm{~s}$ rDNA sequences which were sequenced by Source Bioscience Life Sciences, using the same primers. The resulting sequences were used to identify the closest match to the $16 \mathrm{~s}$ rDNA sequences of the isolates using the BLAST online tool, http://blast.ncbi. nlm.nih.gov/Blast.cgi.

\section{Competing interests}

The authors declare that this work was funded in a joint project between Universities of Nottingham and Reading and BBSRC Rothamsted Experimental Research Station. These organizations do not have anything to gain financially from the publication of this manuscript. There are no competing financial or non-financial interests in the manuscript.

\section{Authors' contributions}

EBS carried out the in vitro predation assay and in vivo mushroom studies, participated in SEM imaging, carried out phylogenetic analyses, and drafted the manuscript. RWJ provided the P. tolaasii strain used in this study, and helped to draft the manuscript. SB was an undergraduate who participated in the in vivo mushroom studies. TS prepared mushroom samples for SEM, and carried out SEM imaging. RES conceived of the study and participated in its design and coordination, and helped to draft and edit the manuscript. All authors saw and approved a final edited version of the manuscript.

\section{Acknowledgements \\ This research was funded through the Nottingham-Reading-Rothamsted Global Food Security tripartite initiative. We thank Laura Hobley for her advice with the predation assay, which was adapted from initial protocols in a previous study [49], Michael Capeness for assistance with false-colouring in photoshop, and Josephine Gilbert for her advice on mushroom lesion photography and intensity measurement in ImageJ.}

\section{Author details}

'Genetics, School of Life Sciences, University of Nottingham, Medical School, Queen's Medical Centre, Nottingham NG7 2UH, UK. ${ }^{2}$ School of Biological Sciences, University of Reading, Whiteknights, Reading RG6 6AJ, UK.
Received: 21 February 2014 Accepted: 12 June 2014

Published: 20 June 2014

\section{References}

1. Tolaas AG: A bacterial disease of cultivated mushrooms. Phytopathology 1915, 5(1):U51-U55.

2. Cho KH, Kim YK: Two types of ion channel formation of tolaasin, a Pseudomonas peptide toxin. Fems Microbiol Lett 2003, 221(2):221-226.

3. Han HS, Jhune CS, Cheong JC, Oh JA, Kong WS, Cha JS, Lee CJ: Occurrence of black rot of cultivated mushrooms (Flammulina velutipes) caused by Pseudomonas tolaasii in Korea. Eur J Plant Pathol 2012, 133(3):527-535.

4. Nutkins JC, Mortishiresmith RJ, Packman LC, Brodey CL, Rainey PB, Johnstone K, Williams DH: Structure determination of Tolaasin, an extracellular Lipodepsipeptide produced by the mushroom Pathogen Pseudomonas-Tolaasii paine. J Am Chem Soc 1991, 113(7):2621-2627.

5. Rainey PB, Brodey $C L$, Johnstone $\mathrm{K}$ : Biological properties and spectrum of activity of Tolaasin, a Lipodepsipeptide toxin produced by the mushroom pathogen Pseudomonas-Tolaasll. Physiol Mol Plant Pathol 1991, 39(1):57-70.

6. Brodey CL, Rainey PB, Tester M, Johnstone K: Bacterial Blotch disease of the cultivated mushroom is caused by An ion channel forming Lipodepsipeptide toxin. Mol Plant-Microbe Interact 1991, 4(4):407-411.

7. Hutchison $M L$, Johnstone $K$ : Evidence for the involvement of the surfaceactive properties of the extracellular toxin Tolaasin in the manifestation of brown Blotch disease symptoms by Pseudomonas-Tolaasii on Agaricus-Bisporus. Physiol Mol Plant Pathol 1993, 42(5):373-384.

8. Soler-Rivas C, Jolivet S, Arpin N, Olivier JM, Wichers HJ: Biochemical and physiological aspects of brown blotch disease of Agaricus bisporus. Fems Microbiol Rev 1999, 23(5):591-614.

9. Fermor TR, Henry MB, Fenlon JS, Glenister MJ, Lincoln SP, Lynch JM: Development and application of a biocontrol system for bacterial Blotch of the cultivated mushroom. Crop Prot 1991, 10(4):271-278.

10. Gonzalez AJ, Gonzalez-Varela G, Gea FJ: Brown Blotch caused by Pseudomonas tolaasii on Cultivated Pleurotus eryngii in Spain. Plant Dis 2009, 93(6):667-677.

11. Milijasevic-Marcic S, Todorovic B, Potocnik I, Stepanovic M, Rekanovic E: First report of Pseudomonas tolaasii on Agaricus bisporus in Serbia. Phytoparasitica 2012, 40(3):299-303.

12. Goor M, Vantomme R, Swings J, Gillis M, Kersters K, Deley J: Phenotypic and genotypic diversity of Pseudomonas-Tolaasll and white line reacting organisms isolated from cultivated mushrooms. J Gen Microbiol 1986, 132:2249-2264.

13. Zhang RY, Hu DD, Gu JG, Zuo XM, Hu QX, Zhang JX: Evaluation of oyster mushroom strains for resistance to Pseudomonas tolaasii by inoculation in spawned substrates. Eur J Plant Pathol 2013, 137(1):119-126.

14. Preece TF, Wong WC: Uantitative and scanning electron-microscope observations on the attachment of Pseudomonas-Tolaasll and other bacteria to the surface of Agaricus-bisporus. Physiol Plant Pathol 1982, 21(2):251.

15. Zarenejad F, Yakhchali B, Rasooli I: Evaluation of indigenous potent mushroom growth promoting bacteria (MGPB) on Agaricus bisporus production. World J Microbiol Biotechnol 2012, 28(1):99-104.

16. Wong WC, Preece TF: Pseudomonas-tolaasi in mushroom crops - a note on primary and secondary sources of the bacterium on a commercial farm in England. J Appl Bacteriol 1980, 49(2):305-314.

17. Han B, Pain A, Johnstone K: Spontaneous duplication of a 661 bp element within a two-component sensor regulator gene causes phenotypic switching in colonies of Pseudomonas tolaasii, cause of brown blotch disease of mushrooms. Mol Microbiol 1997, 25(2):211-218.

18. Sinha $\mathrm{H}$, Pain $\mathrm{A}$, Johnstone $\mathrm{K}$ : Analysis of the role of recA in phenotypic switching of Pseudomonas tolaasii. J Bacteriol 2000, 182(22):6532-6535.

19. Grewal SIS, Rainey PB: Phenotypic variation of Pseudomonas-Putida and P-Tolaasll affects the Chemotactic response to Agaricus-Bisporus Mycelial exudate. J Gen Microbiol 1991, 137:2761-2768.

20. Wells JM, Sapers GM, Fett WF, Butterfield JE, Jones JB, Bouzar H, Miller FC: Postharvest discoloration of the cultivated mushroom Agaricus bisporus caused by Pseudomonas tolaasii, P-'reactans', and P-'gingeri'. Phytopathology 1996, 86(10):1098-1104.

21. Royse DJ, Wuest PJ: Mushroom brown Blotch - effects of chlorinated water on disease intensity and bacterial-populations in casing soil and on pilei. Phytopathology 1980, 70(9):902-905. 
22. Sahin N: Antimicrobial activity of Streptomyces species against mushroom blotch disease pathogen. J Basic Microbiol 2005, 45(1):64-71.

23. Dawoud MEA, Eweis M: Phytochemical control of edible mushrooms pathogenic bacteria. J Food Agric Environ 2006, 4(1):321-324.

24. Soler-Rivas C, Arpin N, Olivier JM, Wichers HJ: WLIP, a lipodepsipeptide of Pseudomonas 'reactans', as inhibitor of the symptoms of the brown blotch disease of Agaricus bisporus. J App/ Microbiol 1999, 86(4):635-641.

25. Parret AHA, Temmerman K, De Mot R: Novel lectin-like bacteriocins of biocontrol strain Pseudomonas fluorescens Pf-5. Appl Environ Microbiol 2005, 71(9):5197-5207.

26. Nguyen HTD, Yoon S, Kim M-H, Kim Y-K, Yoon M-Y, Cho Y-H, Lim Y, Shin SH, Kim D-E: Characterization of bacteriophage $\varphi$ Pto-bp6g, a novel phage that lyses Pseudomonas tolaasii causing brown blotch disease in mushrooms. J Microbiol Methods 2012, 91(3):514-519.

27. Lambert C, Morehouse KA, Chang C-Y, Sockett RE: Bdellovibrio: growth and development during the predatory cycle. Curr Opin Microbiol 2006, 9(6):639-644.

28. Sockett RE, Lambert C: Bdellovibrio as therapeutic agents: a predatory renaissance? Nat Rev Microbio/ 2004, 2(8):669-675.

29. Stolp H, Starr MP: Bdellovibrio bacteriovorus gen. et sp. n., a predatory, ectoparasitic, and bacteriolytic microorganism. Antonie Van Leeuwenhoek J Microbiol Serol 1963, 29(3):217.

30. Lambert C, Evans KJ, Till R, Hobley L, Capeness M, Rendulic S, Schuster SC, Aizawa SI, Sockett RE: Characterizing the flagellar filament and the role of motility in bacterial prey-penetration by Bdellovibrio bacteriovorus. Mol Microbiol 2006, 60(2):274-286.

31. Lambert C, Fenton AK, Hobley L, Sockett RE: Predatory bdellovibrio bacteria Use gliding motility to scout for prey on surfaces. J Bacteriol 2011, 193(12):3139-3141.

32. Lambert C, Smith MCM, Sockett RE: A novel assay to monitor predatorprey interactions for Bdellovibrio bacteriovorus $109 \mathrm{~J}$ reveals a role for methyl-accepting chemotaxis proteins in predation. Environ Microbiol 2003, 5(2):127-132.

33. Atterbury RJ, Hobley L, Till R, Lambert C, Capeness MJ, Lerner TR, Fenton AK, Barrow $P$, Sockett RE: Effects of orally administered bdellovibrio bacteriovorus on the well-being and salmonella colonization of young chicks. Appl Environ Microbiol 2011, 77(16):5794-5803.

34. Scherff $\mathrm{RH}$ : Control of bacterial blight of soybean by Bdellovibrio bacteriovorus. Phytopathology 1973, 63(3):400-402.

35. Frey-Klett $P$, Burlinson $P$, Deveau A, Barret $M$, Tarkka M, Sarniguet $A$ : Bacterial-fungal interactions: hyphens between agricultural, clinical, environmental, and food microbiologists. Microbiol Mol Biol Rev 2011 75(4):583-+.

36. Rainey PB: Phenotypic variation of Pseudomonas-Putida and P-Tolaasll affects attachment to Agaricus-Bisporus mycelium. J Gen Microbiol 1991, 137:2769-2779.

37. Russo A, Filippi C, Tombolini R, Toffanin A, Bedini S, Agnolucci M, Nuti M: Interaction between gfp-tagged Pseudomonas tolaasii P12 and Pleurotus eryngii. Microbiol Res 2003, 158(3):265-270.

38. Morehouse KA, Hobley L, Capeness M, Sockett RE: Three motAB stator gene products in bdellovibrio bacteriovorus contribute to motility of a single flagellum during predatory and prey-independent growth. J Bacteriol 2011, 193(4):932-943.

39. Sajben E, Manczinger L, Nagy A, Kredics L, Vagvolgyi C: Characterization of pseudomonads isolated from decaying sporocarps of oyster mushroom. Microbiol Res 2011, 166(4):255-267.

40. Shankar M, Ponraj P, llakkiam D, Gunasekaran P: Root colonization of a rice growth promoting strain of Enterobacter cloacae. J Basic Microbiol 2011, 51(5):523-530.

41. Watabe M, Rao JR, Xu J, Millar BC, Ward RF, Moore JE: Identification of novel eubacteria from spent mushroom compost (SMC) waste by DNA sequence typing: ecological considerations of disposal on agricultural land. Waste Manag 2004, 24(1):81-86.

42. Dashiff A, Junka RA, Libera M, Kadouri DE: Predation of human pathogens by the predatory bacteria Micavibrio aeruginosavorus and Bdellovibrio bacteriovorus. J Appl Microbiol 2011, 110(2):431-444.

43. Koval SF, Hynes SH: Effect of Paracrystalline protein surface-layers on predation by bdellovibrio-Bacteriovorus. J Bacterio/ 1991, 173(7):2244-2249.

44. Simon LD, Randolph B, Irwin N, Binkowski G: Stabilization of Proteins by a bacteriophage-T4 gene cloned in Escherichia coli. Proc Natl Acad Sci USA Biol Sci 1983, 80(7):2059-2062.
45. Rendulic S, Jagtap P, Rosinus A, Eppinger M, Baar C, Lanz C, Keller H, Lambert C, Evans KJ, Goesmann A, Meyer F, Sockett RE, Schuster SC: A predator unmasked: Life cycle of Bdellovibrio bacteriovorus from a genomic perspective. Science 2004, 303(5658):689-692.

46. Paine SG: Studies in bacteriosis II A brown blotch disease of cultivated mushrooms. Ann Appl Biol 1919, 5(3-4):206-219.

47. Muyzer G, Teske A, Wirsen CO, Jannasch HW: Phylogenetic-relationships of Thiomicrospira species and their identification in deep-sea hydrothermal vent samples by denaturing gradient gel-electrophoresis of 16S RDNA Fragments. Arch Microbiol 1995, 164(3):165-172.

48. Capeness MJ, Lambert C, Lovering AL, Till R, Uchida K, Chaudhuri R, Alderwick LJ, Lee DJ, Swarbreck D, Liddell S: Activity of Bdellovibrio Hit locus proteins, Bd0108 and Bd0109, links type IVa Pilus extrusion/ retraction status to prey-independent growth signalling. PLOS One 2013 8(11):e79759.

49. Hobley L, King JR, Sockett RE: Bdellovibrio predation in the presence of decoys: Three-way bacterial interactions revealed by mathematical and experimental analyses. Appl Environ Microbiol 2006, 72(10):6757-6765.

doi:10.1186/1471-2180-14-163

Cite this article as: Saxon et al:: Bdellovibrio bacteriovorus HD100 guards against Pseudomonas tolaasii brown-blotch lesions on the surface of post-harvest Agaricus bisporus supermarket mushrooms. BMC Microbiology 2014 14:163.

\section{Submit your next manuscript to BioMed Central and take full advantage of:}

- Convenient online submission

- Thorough peer review

- No space constraints or color figure charges

- Immediate publication on acceptance

- Inclusion in PubMed, CAS, Scopus and Google Scholar

- Research which is freely available for redistribution 